\title{
Epidemiology of canine visceral leishmaniosis in the endemic area of Montes Claros Municipality, Minas Gerais State, Brazil
}

\author{
João C. França-Silva ${ }^{a}$, Roberto T. da Costa ${ }^{a}$, Ari M. Siqueira ${ }^{b}$, \\ George L.L. Machado-Coelho ${ }^{\mathrm{c}}$, Carlos A. da Costa ${ }^{\mathrm{a}}$, \\ Wilson Mayrink ${ }^{a}$, Edva P. Vieira ${ }^{\mathrm{d}}$, Jaime S. Costa ${ }^{\mathrm{d}}$, Odair Genaro ${ }^{\mathrm{a}}$, \\ Evaldo Nascimento ${ }^{\mathrm{a}, *}$ \\ a Departamento de Parasitologia, Laboratorio de Leishmanioses and Vacinas, Instituto de Ciências Biológicas, \\ Universidade Federal de Minas Gerais, Av. Antonio Carlos 6627, Pampulha 31270-901, \\ Belo Horizonte, $M G$, Brazil \\ ${ }^{\mathrm{b}}$ Departamento de Bioquímica e Imunologia, Instituto de Ciências Biológicas, \\ Universidade Federal de Minas Gerais, Belo Horizonte, Brazil \\ ${ }^{\mathrm{c}}$ Escola de Farmácia, Universidade Federal de Ouro Preto, Ouro Preto, MG, Brazil \\ ${ }^{\mathrm{d}}$ Fundação Nacional de Saúde, Ministério da Saúde, Minas Gerais, Brazil
}

Received 6 November 2001; received in revised form 23 September 2002; accepted 15 October 2002

\begin{abstract}
The Montes Claros City is located in an endemic area for visceral leishmaniosis in the Minas Gerais State, Brazil. With the implementation of a program for the control of visceral leishmaniosis in 1994, a sectional study was carried out to evaluate the infection by viscerotropic Leishmania in the population of dogs from Montes Claros, basically using indirect immunofluorescence antibody test (IFAT). Blood samples were collected on filter paper from 33,937 dogs, representing $96.1 \%$ of the canine local population. The prevalence for visceral leishmaniosis was found to be $9.7 \%$ in the municipality, being $9.9 \%$ in the urban area and $8.8 \%$ in the rural area. The annual incidence showed to be $64.3 / 1000$ dogs. Prevalence of infection was not correlated with dogs age. The most affected breeds were: Boxer (24.6\%) and Cocker (26.9\%); Mongrel dogs had a prevalence of $7.8 \%$. Short-hair animals had a prevalence of $11.9 \%$, while long-furred animals had a prevalence of $8.9 \%$. The isoenzymatic profile indicated that Leishmania (Leishmania) chagasi was the visceral leishmaniosis etiological agent in Montes Claros City, Minas Gerais State, Brazil. The main geographical areas for the parasite transmission were identified, and control measures were immediately started. The role of the dog as a reservoir for L. chagasi was confirmed. It was demonstrated
\end{abstract}

\footnotetext{
* Corresponding author. Tel.: +55-31-3499-2859; fax: +55-31-3499-2859.

E-mail address: evaldo@icb.ufmg.br(E. Nascimento).
} 
that short-furred animals are at a higher risk of acquiring visceral leishmaniosis than the long-furred dogs.

(c) 2002 Elsevier Science B.V. All rights reserved.

Keywords: Dog; Canine visceral leishmaniosis; Leishmania (Leishmania) chagasi; Epidemiology

\section{Introduction}

In the American continent Leishmania (Leishmania) chagasi is the causative agent of human and canine visceral leishmaniosis (HVL, CVL). Dogs play an important role in the maintenance of these disease in the human environment serving as reservoirs for this intracellular parasite (Deane and Deane, 1962; Quinnell et al., 1997). The prevalence for CVL in Brazil has been demonstrated to be between 1.9 and 25\% in endemic areas (Sherlock and Almeida, 1970; Magalhães et al., 1980; Iverson et al., 1983; Coutinho et al., 1985).

Studies on risk factors associated with animal breeds, gender and age are few and not always consensual. As for the animals age, there seems to be an increased prevalence for L. chagasi associated with the animals growth (Alencar and Cunha, 1963; Pozio et al., 1981; Azevedo and Neves, 1963; Lanotte et al., 1975; Sideris et al., 1996). Abranches et al. (1991a) demonstrated the disease only in young adults and old dogs. No specific patterns were found for CVL as for gender distribution of those dogs in Brazil (Alencar and Cunha, 1963). Similar results were found by Pozio et al. (1981) in Italy, Abranches et al. (1991a) in Portugal, and Sideris et al. (1996) in Greece. However, Lanotte et al. (1975) found higher significant prevalence of CVL in male dogs in France.

Concerning different breeds, Ranque et al. (1997) have demonstrated that the German Shepherd and Boxer dogs were the ones with higher prevalence of infection in France. In Portugal, Abranches et al. (1991b) reported a high incidence in Doberman and German Shepherd dogs. Sideris et al. (1996) in Athens, Greece, found that Collie dogs was the less infected breed, and the Doberman was the most susceptible dog for CVL, also their findings showed that this short-furred animal was more easily bitten by sand flies. They also remarked, however, that other factors such as breed, habits and immunological status could be associated with susceptibility to infection by visceral Leishmaniosis. In Italy, Pozio et al. (1981) could not demonstrate breed-related specific prevalence. In regards to the breed's groups, Hasibeder et al. (1992) observed in the Island of Gozo, in Malta, that the infection rate for working breeds was three times higher in comparison with companion dogs. In this matter, Abranches et al. (1991a) found different findings in Portugal.

Knowledge on natural history of CVL should enable a solid basis control program (Dye et al., 1993). However, good planning should be exercised so as to consider basic quantitative information about the disease's prevalence and incidence, among other parameters. The primary goal of this research was to characterize the different aspects of CVL in the endemic area of Montes Claros City, Minas Gerais State, Brazil, to support the implementation of some strategy for epidemiological control of the disease. 


\section{Methodology}

\subsection{Geographical area under study}

The municipality of Montes Claros City is located in the northern region of the Minas Gerais State, occupying an area of $4135 \mathrm{~km}^{2}$, within the named dry-land polygon of Brazil (Fig. 1). It comprises eight districts with 320 farms, 10 small villages, four villages and two smaller rural areas, including 112 urban "boroughs" which is part of the Montes Claros City. The administrative center of the municipality is located at $16.42^{\prime} 16^{\prime \prime} \mathrm{S}, 43.49^{\prime} 13^{\prime \prime} \mathrm{W}$. Data on weather condition were provided by the Fifth District Weather Studies Center of Minas Gerais State.

The region, in which Montes Claros is located, was characterized as savanna-like vegetation known as "cerrado", with a rainy season extending from October to March (Spring and Summer) resulting in an annual average rainfall of $520 \mathrm{~mm}$. Yearly, the relative humidity varies from 52 to $80 \%$.

The population was estimated in 260,000 inhabitants, where $30 \%$ of the people live in rural areas. The city has a population density of 63 habitants $/ \mathrm{km}^{2}$. A permanent influx of dogs originating from several regions results from a long and constant human migration from the county to Montes Claros.

\subsection{Canine population survey}

The survey was performed in 35,293 dogs domiciled in Montes Claros City in 1994. These data represented $97.5 \%$ of the whole canine population in the area. A number of 893

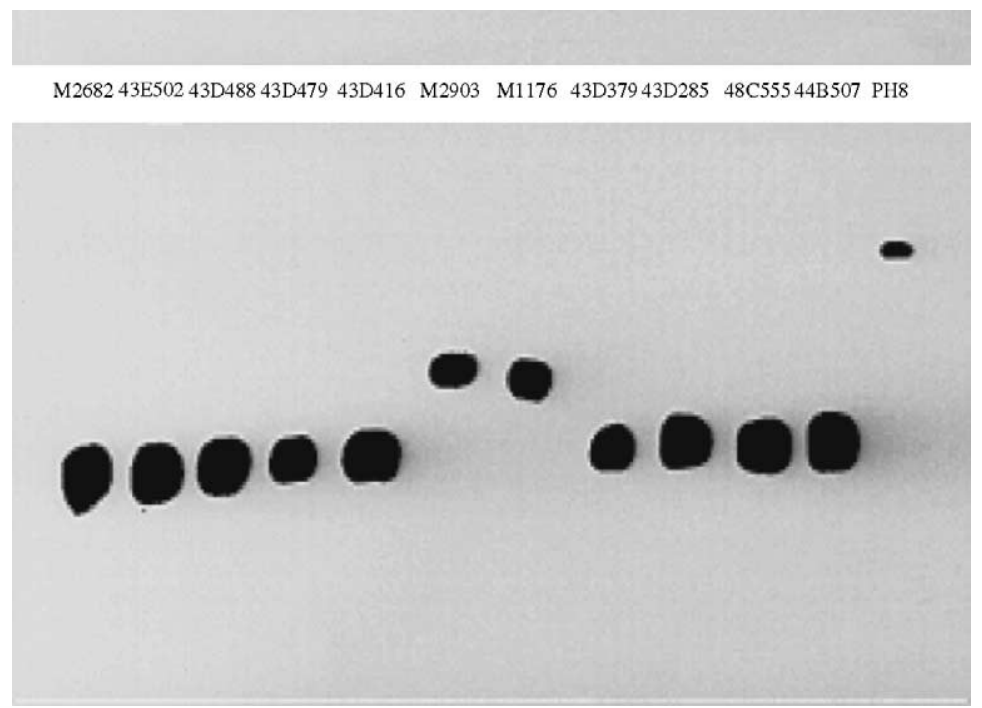

Fig. 1. Glucose phosphate isomerase electrophoretic profiles for the Leishmania strains isolates: M2682, 43E502, 43D488, 43D479, 43D416, M2903, M1176, 43D379, 43D285, 48C555, 44B507 and PH8. 
dogs were excluded from the survey because of their owners refusal. Total 33,937 animals were examined, their data were fully computed and used for further statistical analysis. A 1356 animals (3.8\% of the total examined) had their data lost or incompletely recorded being also excluded from the study.

Blood samples were collected on filter paper from all animals included in this study (Coutinho et al., 1985) and sent to the laboratory to perform immunofluorescence antibody test (IFAT) according to Camargo and Rebonato (1969). Additional data such as the dog's name, sex, age, breed and phenotypic description, their owners, residential address and location of the domicile in the city were recorded at the time of blood collection on filter paper (Wartman 1, Klabin Co., Brazil).

In this test, promastigote form from Leishmania (Leishmania) mexicana (strain MHOM/ BR/1960/BH6), in exponential phase of growth in liver infusion trypticase medium (LIT) (Camargo and Rebonato, 1969), as antigen and anti-dog IgG fluorescent-conjugated antibodies, from Biomanguinhos, Owaldo Cruz Foundation (FIOCRUZ) were used in the IFAT. The discriminative dilution for IFAT was 1:40, according to Costa et al. (1991).

The breeds were identified according to the American Kennel Club (USA), which recognizes 147 breeds of dogs. The IFAT-positive animals to Leishmania antigen were confiscated and eliminated in the Center for Disease Control, in Montes Claros, administrated by National Health Foundation, Brazil.

\subsection{Statistical analysis and data processing}

The morbidity indexes for CVL were calculated following the formulas: (a) $P=(C / D) \times$ 100 , where $P$ represents the prevalence rate in a certain interval of time (during 1994), $C$ the number of cases observed in the study area in a interval of time, and $D$ represents the number of dogs at risk of acquiring the infection within the same interval of time; (b) $I=$ $(C / D) \times 1000$, where $I$ represents the incidence rate in a interval of time (February-June 1994), $C$ the number of new cases detected in the study area within the specified time interval, and $D$ represents the number of dogs at risk of acquiring the infection, within the same time interval (Beaglehole et al., 1993).

The chi-square with Yates' correction were used for comparison of proportions, using region, breed, fur type, age and gender as independent variables and the prevalence and incidence rates as dependent variables (Snedecor and Cochran, 1989).

Data were coded to be inputted in the software package Epi Info 6.04 (Dean et al., 1990), and analysis performed by SPSS 8.0 (Norussis, 1990).

Data were coded to be inputted in the software package Phylip version 3.5p. The software packages MS-Access 6.0 (Microsoft Corp., Seattle, WA), SPSS 6.0 (SPSS Inc., Chicago, IL) and the Centers for Disease Control's Epi Info 6.0 were also used.

\subsection{Leishmania isoenzymatic typing}

Thirty-four necropsies were performed in seropositive dogs in the urban area, from which 18 stocks of Leishmania were isolated and isoenzymatically characterized after cultivation at $23^{\circ} \mathrm{C}$ in NNN (Nicolle, 1908) and/or LIT medium. A biphasic medium, NNN/LIT, was also used to obtain larger amounts of promastigote (Costa et al., 1983). 
Cellular homogenates were prepared and stored in liquid nitrogen. Comparative isoenzymatic studies were conducted using different stocks of parasites, such as: Leishmania (L.) amazonensis (IFLA/BR/1967/PH8), Leishmania (V.) guyanensis (MHOM/BR/1970/ M1176), Leishmania (L.) chagasi (MHOM/BR/1974/M2682), Leishmania (V.) braziliensis (MHOM/BR/1975/M2903) using the enzymes ALAT, ASAT, ME, PGM, 6PGD, G6PD, GPI, HK, ICD, MDH, MPI, PEP-1, PEP-2 and PK according to Kilgour and Godfrey (1973).

\section{Results}

In this research, a number of 33,937 dogs were examined in rural and urban areas of Montes Claros City. The prevalence of the disease in both areas showed to be 8.8 and $9.9 \%$, respectively, or $9.7 \%$ as a global value. The difference between rural and urban areas was statistically significant $\left(\chi^{2}=8.09, P=0.004\right.$, Table 1$)$.

In order to calculate CVL prevalence, 336 localities (14 villages and 322 farms), with one or more dogs, had the areas divided into 18 blocks such as I-XVIII, according to their locations, borders and geographical isolation by rivers or mountains (Table 2, Fig. 2). In the rural area, 7391 dogs were examined in 336 localities. A 656 dogs had antibodies against Leishmania detected by IFAT in $56.2 \%$ of the localities. The prevalence in this area ranged from 2.9 to $15.3 \%$ with a global value of $8.8 \%$. The blocks V, VII, VIIII, IX and XVIII had higher prevalence in comparison with other blocks (Table 2).

In Montes Claros, divided into north, south, east, west and central regions, the boroughs per region varied from 10 to 31, in which 26,546 dogs were examined. Only six out of 112 boroughs under investigation did not have IFAT-positive dogs. The prevalence per geographical regions were 10.1, 8.0, 9.4, 12.7 and 11.7, respectively, with a global value of $9.9 \%$ (Table 3).

During the period from February to June 1994, 236 animals (15.7\%) were considered lost due to the mortality caused by CVL, hemorrhagic gastroenteritis, malnutrition, accidents, poisoning, elimination by rabies control programs, other natural causes or emigration with their owners. Out of 1269 dogs analyzed at this time, 34 animals acquired Leishmania infection, resulting in an incidence of $64.3 / 1000 \mathrm{dogs}$ per year $\left(\mathrm{CI}_{95 \%}=57.2-71.4\right)$. In the analysis of the population of 26,546 animals (Table 3), 1707 new cases of CVL were notified in the current year, maintaining the transmissibility for the urban area of Montes Claros (data not shown).

Eleven short-furred and six long-furred breeds were identified. The long/short-fur Mongrel dogs were also located. Based on these animal distribution, 25,920 dogs were evaluated.

Table 1

Prevalence of the canine visceral leishmaniosis in the municipality of Montes Claros City, Minas Gerais State, Brazil

\begin{tabular}{llllll}
\hline Areas & $\begin{array}{l}\text { Relative } \\
\text { distribution }(\%)\end{array}$ & $\begin{array}{l}\text { Number of } \\
\text { dogs examined }\end{array}$ & $\begin{array}{l}\text { IFAT-positive } \\
\text { dogs }\end{array}$ & $\begin{array}{l}\text { Prevalence } \\
(\%)\end{array}$ & $\begin{array}{l}\text { Confidence } \\
\text { interval }(95 \%)\end{array}$ \\
\hline Rural & 21.8 & 7,391 & 656 & 8.8 & $8.1-9.4$ \\
Urban & 78.2 & 26,546 & 2644 & 9.9 & $9.5-10.2$ \\
Total & 100.0 & 33,937 & 3300 & 9.7 & $9.3-10.0$ \\
\hline
\end{tabular}


Table 2

Prevalence of the canine visceral leishmaniosis according to localities (blocks) in the rural area of Montes Claros City, Minas Gerais State, Brazil

\begin{tabular}{lccccc}
\hline Blocks & $\begin{array}{l}\text { Number of } \\
\text { localities }\end{array}$ & $\begin{array}{l}\text { Dogs } \\
\text { examined }\end{array}$ & $\begin{array}{l}\text { IFAT-positive } \\
\text { dogs }\end{array}$ & $\begin{array}{l}\text { Prevalence } \\
(\%)\end{array}$ & $\begin{array}{l}\text { Confidence } \\
\text { interval }(95 \%)\end{array}$ \\
\hline I & 11 & 133 & 5 & 3.8 & $0.5-7.0$ \\
II & 9 & 136 & 4 & 2.9 & $0.0-5.7$ \\
III & 14 & 235 & 19 & 8.1 & $4.6-11.5$ \\
IV & 22 & 337 & 24 & 7.1 & $4.3-9.8$ \\
V & 9 & 135 & 18 & 13.3 & $7.5-19.0$ \\
VI & 16 & 525 & 21 & 4.0 & $2.3-5.6$ \\
VII & 34 & 769 & 118 & 15.3 & $12.7-17.8$ \\
VIII & 45 & 939 & 121 & 12.9 & $10.7-15.0$ \\
IX & 19 & 454 & 46 & 10.1 & $7.3-12.8$ \\
X & 26 & 585 & 49 & 8.4 & $6.1-10.6$ \\
XI & 5 & 100 & 9 & 9.0 & $3.3-14.6$ \\
XII & 26 & 909 & 55 & 6.1 & $4.5-7.6$ \\
XIII & 19 & 312 & 14 & 4.5 & $2.2-6.7$ \\
XIV & 9 & 224 & 11 & 4.9 & $2.0-7.7$ \\
XV & 21 & 493 & 34 & 6.9 & $4.6-9.1$ \\
XVI & 12 & 250 & 19 & 7.6 & $4.3-10.8$ \\
XVII & 19 & 325 & 25 & 7.7 & $4.8-10.5$ \\
XVIII & 20 & 530 & 64 & 12.1 & $9.3-14.8$ \\
Total & 336 & 7391 & 656 & 8.8 & $8.1-9.4$ \\
\hline
\end{tabular}

The prevalence of the disease ranged from 5 to $24.6 \%$ for short-fur dogs. In this group, a higher prevalence of 17, 24.6 and 19.1 were observed for Doberman, Boxer and Great Dane, respectively. For the long-fur group a higher prevalence (26.9\%) was observed for Coker Spaniel breed dogs (Table 4). For Mongrel dogs, a prevalence of $7.8 \%$ was obtained. The most numerous breed was Pekingese representing $5.6 \%$ of the population. IFAT-positive dogs were observed in all breeds (Table 4). Dalmatians, Weimaraner, Boxer, Siberian Husky, Belgium Sheepdog, Fox Terrier, Great Dane and Chihuahua had the smallest prevalence. Boxer and Cocker had a prevalence greater than expected, 24.6 and $26.9 \%$, respectively. Such data can be ascribed to the higher susceptibility of these breeds to L. chagasi infected bets (Table 4).

Table 3

Prevalence of the canine visceral leishmaniosis per geographical region in the urban area of Montes Claros City, Minas Gerais State, Brazil

\begin{tabular}{lcccccc}
\hline Region & $\begin{array}{l}\text { Number of } \\
\text { boroughs }\end{array}$ & $\begin{array}{l}\text { Relative } \\
\text { distribution }(\%)\end{array}$ & $\begin{array}{l}\text { Dogs } \\
\text { examined }\end{array}$ & $\begin{array}{l}\text { IFAT-positive } \\
\text { dogs }\end{array}$ & $\begin{array}{l}\text { Prevalence } \\
(\%)\end{array}$ & $\begin{array}{l}\text { Confidence } \\
\text { interval }(95 \%)\end{array}$ \\
\hline North & 29 & 22.9 & 6,081 & 615 & 10.1 & $9.3-10.8$ \\
South & 31 & 23.3 & 6,191 & 500 & 8.0 & $7.3-8.6$ \\
East & 25 & 27.7 & 7,354 & 693 & 9.4 & $8.9-10.2$ \\
West & 10 & 8.3 & 2,202 & 280 & 12.7 & $11.3-14.0$ \\
Central & 17 & 17.8 & 4,718 & 556 & 11.7 & $10.7-12.6$ \\
Total & 112 & 100.0 & 26,546 & 2644 & 9.9 & $9.5-10.2$ \\
\hline
\end{tabular}

\footnotetext{
${ }^{\mathrm{a}} \chi^{2}=64.15, P<0.05$.
} 


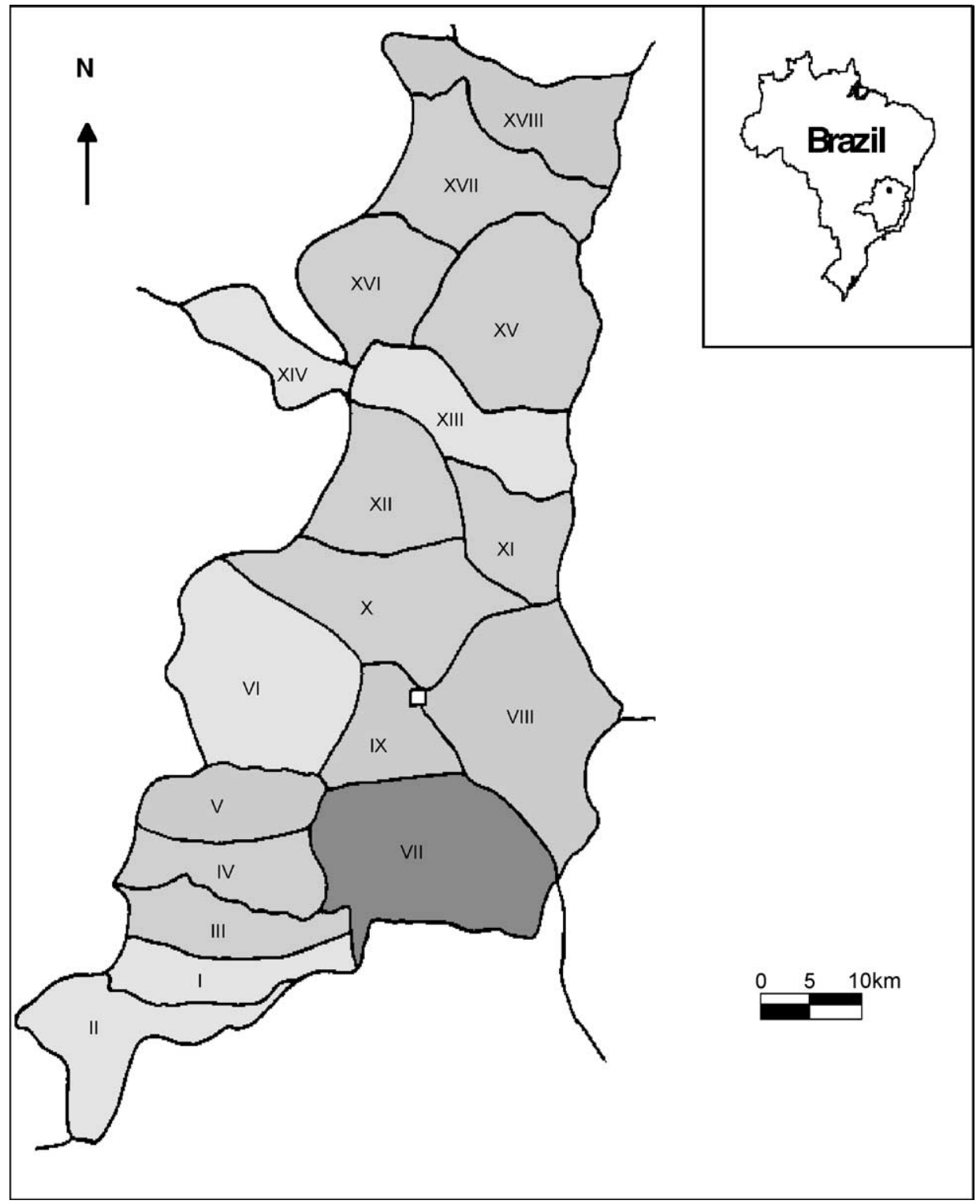

Fig. 2. Physical map of the working area of the municipality of Montes Claros City, Minas Gerais State, Brazil (scale: 1:200,000).

The animals with defined breed were grouped into "long-furred" and "short-furred" dogs (Table 5). The long-furred group included Poodles, German Shepherd dogs, Pekingeses, Siberian Huskies, Belgium Sheepdogs and Cockers; the short-furred were Chihuahuas, Brazilians Fila, Pinschers, Dalmatians, Dachshunds, Weimaraners, Dobermans, Boxers, 
Table 4

Prevalence of the canine visceral leishmaniosis, by breed and fur type in the Montes Claros City, Minas Gerais State, Brazil

\begin{tabular}{|c|c|c|c|c|c|c|}
\hline Breed & Fur type & $\begin{array}{l}\text { Relative } \\
\text { distribution }(\%)\end{array}$ & $\begin{array}{l}\text { Dogs } \\
\text { examined }\end{array}$ & $\begin{array}{l}\text { IFAT-positive } \\
\text { dogs }\end{array}$ & $\begin{array}{l}\text { Prevalence } \\
(\%)\end{array}$ & $\begin{array}{l}\text { Confidence } \\
\text { interval }(95 \%)\end{array}$ \\
\hline American Pointer & Short & 2.7 & 689 & 64 & 9.3 & $7.1-11.4$ \\
\hline Brazilian Fila & Short & 5.0 & 1,285 & 148 & 11.5 & $9.7-13.2$ \\
\hline Chihuahua & Short & 1.4 & 361 & 20 & 5.5 & $3.1-7.8$ \\
\hline Doberman & Short & 1.8 & 453 & 77 & 17.0 & $13.5-20.4$ \\
\hline Dachshund & Short & 1.2 & 293 & 39 & 13.3 & $9.4-17.1$ \\
\hline Dalmatian & Short & 0.2 & 56 & 7 & 12.5 & $3.8-21.1$ \\
\hline Boxer & Short & 0.2 & 57 & 14 & 24.6 & $13.4-35.7$ \\
\hline Fox Terrier & Short & 0.1 & 37 & 4 & 10.8 & $0.7-20.8$ \\
\hline Great Dane & Short & 0.3 & 89 & 17 & 19.1 & $10.9-27.2$ \\
\hline Pinscher & Short & 1.9 & 497 & 43 & 8.7 & $6.2-11.1$ \\
\hline Weimaraner & Short & 0.1 & 31 & 2 & 6.5 & $2.1-15.1$ \\
\hline $\begin{array}{l}\text { Belgium } \\
\text { Sheepdog }\end{array}$ & Long & 0.2 & 54 & 4 & 7.4 & $0.4-14.3$ \\
\hline Cocker Spaniel & Long & 0.1 & 26 & 7 & 26.9 & $9.8-43.9$ \\
\hline $\begin{array}{l}\text { German } \\
\quad \text { Shepherd dog }\end{array}$ & Long & 7.0 & 1,801 & 227 & 12.6 & $11.0-14.1$ \\
\hline Pekingese & Long & 7.3 & 1,895 & 116 & 6.1 & $5.0-7.1$ \\
\hline Poodle & Long & 1.6 & 418 & 28 & 6.7 & $4.3-9.0$ \\
\hline Siberian Husky & Long & 0.2 & 59 & 7 & 11.9 & $3.6-20.1$ \\
\hline Mongrel & Long/short & 68.7 & 17,819 & 1384 & 7.8 & $7.8-8.0$ \\
\hline Total & 17 & 100 & 25,920 & 2208 & 8.5 & $8.3-8.7$ \\
\hline
\end{tabular}

Pointers, Fox Terriers and Great Dane. The relative distribution of the breeds, adjusted for the length of the fur, resulted in 57\% long-furred animals. The global prevalence was $10.2 \%$, with prevalence of $9.1 \%$ for the long-furred and $11.3 \%$ for the short-furred dogs $\left(\chi^{2}=10.77, P<0.05\right.$, Table 5).

The age distribution of the dogs was pyramidal, with $34 \%$ of the animals younger than 6 months old, continuously decreasing to $1.5 \%$ of the dogs over 10 years of age (Table 6). The prevalence for CVL ranged from $8.1 \%$ for the animals aged between 7 and 12 months to $12.8 \%$ for the animals between 6 and 7 years of age. All age intervals shoed seropositive animals, which mirrors a high prevalence (Table 6).

Table 5

Prevalence of the canine visceral leishmaniosis following to fur type in the Montes Claros City, Minas Gerais State, Brazil

\begin{tabular}{llllcc}
\hline Fur type & $\begin{array}{l}\text { Relative } \\
\text { distribution } \\
(\%)\end{array}$ & $\begin{array}{l}\text { Dogs } \\
\text { examined }\end{array}$ & $\begin{array}{l}\text { IFAT-positive } \\
\text { dogs }\end{array}$ & Prevalence $^{\text {a }(\%)}$ & $\begin{array}{l}\text { Confidence } \\
\text { interval }(95 \%)\end{array}$ \\
\hline Long & 52.5 & 4253 & 389 & 9.1 & $8.2-9.7$ \\
Short & 47.5 & 3848 & 435 & 11.3 & $10.3-12.3$ \\
Total & 100 & 8101 & 824 & 10.2 & $9.5-10.8$ \\
\hline
\end{tabular}

\footnotetext{
${ }^{\mathrm{a}} \chi^{2}=10.77, P=0.001$.
} 
Table 6

Prevalence of the canine visceral leishmaniosis by dogs age in the Montes Claros City, Minas Gerais State, Brazil

\begin{tabular}{lccccc}
\hline $\begin{array}{l}\text { Age distribution } \\
\text { (in years) }\end{array}$ & $\begin{array}{l}\text { Relative } \\
\text { distribution }(\%)\end{array}$ & $\begin{array}{l}\text { Dogs } \\
\text { examined }\end{array}$ & $\begin{array}{l}\text { Dogs found } \\
\text { positive }\end{array}$ & $\begin{array}{l}\text { Prevalence } \\
(\%)\end{array}$ & $\begin{array}{l}\text { Confidence } \\
\text { interval }(95 \%)\end{array}$ \\
\hline $0-0.6$ & 34.0 & 11,539 & 1213 & 10.5 & $9.9-11.0$ \\
$0.6-1.0$ & 16.7 & 5,690 & 462 & 8.1 & $7.3-8.8$ \\
$1.0-2.0$ & 15.3 & 5,194 & 441 & 8.5 & $7.7-9.2$ \\
$2.0-3.0$ & 11.3 & 3,834 & 372 & 9.7 & $8.7-10.6$ \\
$3.0-4.0$ & 6.7 & 2,257 & 234 & 10.4 & $9.1-11.6$ \\
$4.0-5.0$ & 5.0 & 1,691 & 181 & 10.7 & $9.2-12.1$ \\
$5.0-6.0$ & 3.4 & 1,140 & 116 & 10.2 & $8.4-11.9$ \\
$6.0-7.0$ & 1.5 & 516 & 66 & 12.8 & $9.9-15.6$ \\
$7.0-8.0$ & 2.3 & 764 & 82 & 10.7 & $8.5-12.8$ \\
$8.0-9.0$ & 0.7 & 227 & 21 & 9.3 & $5.5-13.0$ \\
$9.0-10.0$ & 1.6 & 559 & 62 & 11.1 & $8.4-13.7$ \\
Above 10.1 & 1.5 & 526 & 50 & 9.5 & $6.9-12.0$ \\
Total & & & & 9.7 & $9.3-10.0$
\end{tabular}

Table 7

Prevalence of the canine visceral leishmaniosis by sex in Montes Claros City, Minas Gerais State, Brazil

\begin{tabular}{llllll}
\hline Gender & $\begin{array}{l}\text { Dogs } \\
\text { examined }\end{array}$ & $\begin{array}{l}\text { Relative } \\
\text { distribution } \\
(\%)\end{array}$ & $\begin{array}{l}\text { IFAT-positive } \\
\text { dogs }\end{array}$ & Prevalence $\left.{ }^{\text {a }} \%\right)$ & $\begin{array}{l}\text { Confidence } \\
\text { interval }(95 \%)\end{array}$ \\
\hline Male & 20,642 & 60.8 & 2022 & 9.8 & $9.2-10.1$ \\
Female & 13,295 & 39.2 & 1278 & 9.6 & $9.1-10.0$ \\
Total & 33,937 & 100 & 3300 & 9.7 & $9.3-10.0$ \\
\hline
\end{tabular}

$$
{ }^{\mathrm{a}} \chi^{2}=0.38, P=0.538
$$

The prevalence of male $(9.7 \%)$ or female $(9.6 \%)$ dogs showed to be not statistically significant $\left(\mathrm{CI}_{95 \%}=0.92-1.05\right.$, Table 7$)$.

During the study, as many as 34 dogs with CVL were killed and necropsies were undertaken. Their spleens were removed for isolation of the parasite. Clinically, they varied from asymptomatic (animal with no clinical diagnosis of the disease) (32.4\%), oligosymptomatic (presence of alopecia, opaque bristle and weight loss) (35.2\%) and symptomatic (loss of weight, clinically sick), IFAT positive, onychogriphosis, cutaneous lesions and keratoconjunctivitis (32.4\%). All of them had splenomegaly at necropsy, were IFAT positive with clinical signs of visceral leishmaniosis. Leishmania was isolated from 18 dogs. Out of these isolates, eight were isoenzymatically typed according to 14 genetic loci. The isoenzyme profiles pointed to Leishmania, from the donovani complex (Fig. 2).

\section{Discussion}

The work was aimed at studying epidemiological aspects of CVL in the municipality of Montes Claros City, Minas Gerais, Brazil. We found 3.6 times more dogs in the urban than 
in rural area. However, the prevalences showed to be statistically significant with values of $9.9 \%$ for the urban area and $8.8 \%$ for the rural area. Based on these data, we may consider the chance of a dog becoming infected to be the same in both areas. In Brazil, the prevalence for CVL in other endemic areas has shown to vary from 5 to 35\% (Evans et al., 1990; Nunes et al., 1991).

There were dogs domiciled in every rural home visited, attesting the importance of these animals for the countrymen's daily routines. Regarding 336 localities examined, 56.2\% of the dogs were IFAT positive for CVL. In each of the 18 blocks of rural localities, we found IFAT-positive animals for CVL. Most of the blocks were considered to be high risk areas of infection by L. chagasi (Fig. 1).

In $94.6 \%$ of Montes Claros boroughs, we found IFAT-positive dogs for CVL. There were slight differences in the prevalence among the boroughs, such as $0.7 \%$ in "Antonieta Canela" in the south and $46.7 \%$ in "Morrinhos" in the east. The prevalence for each geographical regions varied from $8.0 \%$ in the southern to $12.7 \%$ in the western region. The eastern region had the highest $(27.7 \%)$ canine population, but the second lowest prevalence $(9.4 \%)$. The western region had the smallest population of dogs but the highest prevalence rate. In the western region there was an upper middle class borough, "Ibituruna", located just beneath some carbonate rich elevations, probably an ideal ecosystem for the reproduction of Lutzomyia longipalpis, the incriminated insect vector for visceral leishmaniosis in Brazil (Deane and Deane, 1955, 1962). Many specimens of L. longipalpis were captured in "Ibituruna" district, where the examination and blood sampling of dogs are difficult to be carry out, because the animal owners refuse access and/or resort to private veterinarians for the diagnosis of CVL and these professionals many times decide to treat the dogs. Such behavior results in the maintenance of the disease in the area, thereby lengthening the exposure of infected animals to the sand flies and the subsequent transmission of the parasite to healthy dogs. "Ibituruna" had a prevalence rate higher than expected for CVL. Other boroughs with potentially high transmission risk were found in the northern region (nine boroughs), southern region (four boroughs), eastern region (five boroughs), and central regions (two boroughs), inferred from their higher than expected prevalence. It has been observed therefore that the CVL is widely distributed in the periphery and in the central areas of the Montes Claros City, 21 boroughs out of 112 being identified with a relatively greater risk of transmission. The identification of such areas has consequences for the definition of specific control strategies of CVL, and indicates the urbanization of the disease.

The incidence of CVL, in Montes Claros, was evaluated from the end of the rainy season to the beginning of the dry season, coinciding with the decrease of population densities of the insect vector. Considering that the average incubation period for CVL has shown to be approximately 7.1 months, under experimental condition (Genaro et al., 1992), our data were similar to the transmission that occurred in Montes Claros during the period of higher transmission of the disease.

The most afflicted results were observed for Cocker and Boxer breeds with 26.9 and $24.6 \%$ of prevalence, respectively. These observations can be ascribed to the high susceptibility of these animals to be infected by L. chagasi, because they are not predominantly found in Brazil and little knowledge is available up to present moment. Ranque et al. (1997) demonstrated that the German Shepherd dog and the Boxer were the most affected breeds in France. In our findings the German Shepherd dog was the most affected breeds among the six. 
The evidence of a possible association between dogs fur type and the risk of infection, pointed by Sideris et al. (1996), persuaded us to search for additional evidences in the same direction. We grouped the animal's data accordingly to the prevalence analysis in regards to the fur length. Animals with undefined or uninformed breeds were excluded from the analysis. The risk of short-furred animals in comparison to the long-furred group was significant $\left(\chi^{2}=10.77, P<0.001\right)$, reflecting a causal relationship (Wynder et al., 1987). This phenotype is certainly very conspicuous but literature almost always fails to consider the possible relationship between fur length and risk of infection by viscerotropic Leishmania.

Seropositivity for CVL was found at all ages. In the Old World different investigations have reported an increase of prevalence following aging of the animals (Lanotte et al., 1975; Ranque et al., 1997; Abranches et al., 1991a). A possible explanation for the conflicting results might be due to the different stratification of the ages into intervals. The differences could also be related to the distinctive epidemiological environments, but still unexplained.

Gender distribution of the canine population was 1.6 males per each female. The prevalence was statistically equivalent as $9.8 \%$ for males and $9.6 \%$ for females $\left(\chi^{2}=0.38\right.$, $P>0.05)$. The same sites for relative risk of infection were observed. These data are in agreement with studies developed by Abranches et al. (1991a) in Portugal and Pozio et al. (1981) in Italy. On the other hand, Lanotte et al. (1975) found a higher prevalence of CVL in male dogs in France.

The biochemical markers we used for the identification of the circulating Leishmania, in the area of Montes Claros City, pointed to the complex Leishmania donovani by isoenzymatic analysis or more specifically for L. chagasi (Fig. 2) We observed a significant similarity between the Leishmania specimens isolated in Montes Claros with the reference strain of L. chagasi (MHOM/BR/1974/M2682). Similar data were found in Ceará State, Brazil, where Leishmania that infected humans and dogs belonged to the L. donovani complex (Vasconcelos et al., 1988).

This study revealed the importance of the dog as a reservoir for the etiological agent of the canine visceral leishmaniosis in the Montes Claros City, drawing attention to the growing expansion and urbanization of this disease in the northern region of Minas Gerais State, Brazil. It was also demonstrated that virtually any breed of dogs is susceptible to $L$. chagasi, regardless of gender or age. However, it seems clear that the characteristics of the fur, according to the different breeds, may play an important role in the prevalence rate of infection in this region of Brazil.

\section{Acknowledgements}

We thank Fundação Nacional de Saúde, Ministério da Saúde, and Distrito Regional de Montes Claros for their special support and dedication in the development of this hard work.

\section{References}

Abranches, P., Santos-Gomes, G.M., Rachamin, N., Campino, L., Schnur, L.F., Jaffe, C.L.L., 1991a. An experimental model for canine leishmaniosis. Parasite Immunol. 13, 537-550. 
Abranches, P., Silva-Pereira, M.C.D., Conceição-Silva, F.M., Santos-Gomes, G.M., Janz, J.G., 1991b. Canine leishmaniosis: pathological and ecological factors influencing transmission of infection. J. Parasitol. 77, 557561.

Alencar, J.E., Cunha, R.V., 1963. Inquérito sobre calazar no Ceará-Novos resultados. Rev. Bras. Malariol. D. Trop. $15,391-403$.

Azevedo, J.F., Neves, V.M., 1963. La leishmaniose canine à Lisbonne. Ann. Parasitol. Hum. Comp. 38, $741-755$.

Beaglehole, R., Bonita, R., Kjellström, T., 1993 Epidemiologia Básica. World Health Organization, Geneva, 1993. p. 175.

Camargo, M.E., Rebonato, C., 1969. Cross-reactivity in fluorescence tests for Trypanosoma and Leishmania antibodies. Am. J. Trop. Med. Hyg. 18, 500-505.

Costa, C.A., Michalick, M.S.M., Melo, M.N., Williams, P., Dias, M., Magalhães, P.A., Mayrink, W., Costa, R.T., 1983. Estudo comparativo entre meios de cultura para isolamento de leishmanias. Rev. Farm. Bioq. 5, 7-12.

Costa, C.A., Genaro, O., Lana, M., Magalhães, P.A., Dias, M., Michalick, M.S.M., Melo, M.N., Costa, R.T., Magalhães-Rocha, M.N., Mayrink, W., 1991. Leishmaniose visceral canina: avaliação da metodologia sorológica utilizada em inquéritos epidemiológicos. Rev. Soc. Bras. Med. Trop. 24, 21-25.

Coutinho, S.G., Nunes, M.P., Marzochi, M.C.A., Tramontano, N., 1985. A survey for American cutaneous and visceral leishmaniosis among 1342 dogs from areas in Rio de Janeiro (Brazil), where the human disease occur. Mem. Inst. Oswaldo Cruz 80, 17-22.

Dean, A.G., Dean, J.A., Burton, A.H., Dicker, R.C., 1990. Epi Info, version 5: a word processing, database, and statistics program for epidemiology on micro-computers, Center for Diseases Control, Atlanta, GA, USA.

Deane, L.M., Deane, M.P., 1962. Visceral leishmaniosis in Brazil. Geographical distribution and transmission. Rev. Inst. Med. Trop. São Paulo 4, 149-212.

Dye, C., Killick-Kendrick, R., Vitutia, M.M., Walton, R., Killick-Kendrick, M., Harith, A.E., Guy, M.W., Cañavate, M.-C., Hasibeder, G., 1993. Epidemiology of canine leishmaniosis: prevalence, incidence and basis reproduction number calculated from a cross-sectional serological survey on the Island of Gozo. Parasitology $105,35-41$.

Evans, T.G., Vasconcelos, I.A.B., Lima, J.W., Teixeira, J.M., McAullife, I.T., Lopes, U.G., Pearson, R.D., Vasconcelos, A.W., 1990. Canine visceral leishmaniosis in northeast Brazil: assessment of serodiagnostic methods. Am. J. Trop. Med. Hyg. 42, 118-123.

Genaro, O., Costa, C.A., Breyner, E.T., A, B., Silva, A.R., Trópia, M.J.R., Tafuri, W.L., Dias, M., Mayrink, M., 1992. The course of experimental visceral leishmaniosis in dogs. Mem. Inst. Oswaldo Cruz 87, 105.

Hasibeder, G., Dye, C., Carpenter, J., 1992. Mathematical modelling and theory for estimating the basic reproduction number of canine leishmaniosis. Parasitology 105, 43-53.

Iverson, L.B., Camargo, M.E., Villanova, A., Reichmann, M.I.A.B., Anarade, E.A., Tolenzano, J.E., 1983. Inquérito sorológico para pesquisa de leishmaniose visceral em população canina urbana no Município de São Paulo, Brasil (1979-1982). Rev. Inst. Med. Trop. São Paulo 25, 310-317.

Kilgour, V., Godfrey, D.G., 1973. Species characteristics isoenzymes of two aminotransferases in trypanosomes. Nature (New Biol.) 244, 69-70.

Lanotte, G., Rioux, J.A., Crosset, H., Vollhardt, Y., 1975. Écologie des leishmanioses dans le Sud de la France. VIII. Complément à l'application epidémiologique de la technique d'immunofluorescence: les titres geometrices et arithmetiques moyens dans la leishmaniose canine. Ann. Parasitol. Hum. Comp. 50, 1-5.

Magalhães, P.A., Mayrink, W., Costa, C.A., Melo, M.N., Dias, M., Batista, S.M., Michalick, M.S.M., Williams, P., 1980. Calazar na zona do Rio Doce-Minas Gerais. Resultado das medidas profiláticas. Rev. Inst. Med. Trop. São Paulo 22, 197-202.

Nicolle, C., 1908. Nouvelles acquisitions sur le Kla-zar: cultures inoculations au chien etiologi. C. R. Hebd. Séances et L'aca. Sci. Paris 146, 498-499.

Norussis, M.J., 1990. SPSS/PC+: Statistical Package for Social Science (Computer Program). SPSS Inc., Chicago, 1990.

Nunes, M.P., Jackson, J.M., Carvalho, R.W., Furtado, N.J., Coutinho, S.G., 1991. Serological survey for canine cutaneous and visceral leishmaniosis in area at risk for transmission in Rio de Janeiro where prophylactic measures had been adapted. Mem. Inst. Oswaldo Cruz 86, 411-417.

Pozio, E., Gradoni, L., Bettini, S., Gramicia, M., 1981. Leishmaniosis in Tuscany (Italy). VI. Canine leishmaniosis in the focus of Monte Argentario (Grosseto). Acta Trop. 38, 383-393. 
Quinnell, R.J., Courtenay, O., Garcez, L., Dye, C., 1997. The epidemiology of canine leishmaniosis: transmission rates estimated from a cohort study in Amazonian Brazil. Parasitology 115, 143-156.

Ranque, J.M., Quilici, M., Dunan, S., 1997. Les leishmanioses de la région provençale. Considerations épidemiologiques et écologiques. Colloques Int. CNRS, Écol. Leishmanioses 239, 285-293.

Sherlock, L.A., Almeida, S.P., 1970. Notas sobre calazar canino no Estado da Bahia. Rev. Bras. Malariol. D. Trop. $22,231-242$

Sideris, V.L., Karagouni, E., Papadoupoulou, G., Garifallou, A., Dotsika, E., 1996. Canine visceral leishmaniosis in the great Athens area, Greece. Parasite 3, 125-130.

Snedecor, G.W., Cochran, W.G., 1989. Statistical Methods, 8th ed. Iowa State University Press, Iowa.

Vasconcelos, I.A.B., Vasconcelos, A.W., Momen, H., Grimaldi Jr., G., Alencar, J.E., 1988. Epidemiological studies on American leishmaniosis in Ceará State, Brazil. Molecular characterization of Leishmania isolates. Ann. Trop. Med. Parasitol. 82, 547-554.

Wynder, E.L., Higgins, I.T.T., Gordon, L., 1987. Workshop on guidelines to the epidemiology of weak associations. Preventive Med. 16, 139-212. 